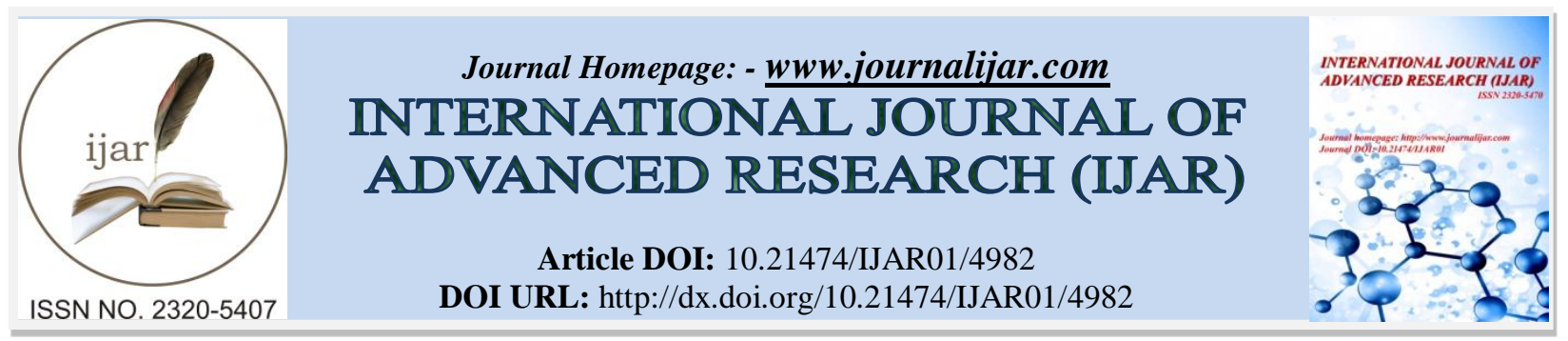

RESEARCH ARTICLE

\title{
MINERAL TRIOXIDE AGGREGATE VERSUS CALCIUM HYDROXIDE IN INDIRECT PULP TREATMENT OF PERMANENT TEETH: A SYSTEMATIC REVIEW.
}

\author{
Marwa Aly ${ }^{1}$, Dalia Moheb ${ }^{1}$, Osama Elshahawy ${ }^{1}$, Ahmed Abd- elsamad ${ }^{2}$ and Mervat Rashed ${ }^{1}$. \\ 1. Pediatric Dentistry and Dental public health, Faculty of Oral and Dental Medicine, Cairo University -Egypt. \\ 2. Oral Radiology, Faculty of Oral and Dental Medicine, Cairo University -Egypt.
}

\section{Manuscript Info}

….......................

Manuscript History

Received: 28 May 2017

Final Accepted: 30 June 2017

Published: July 2017

Key words:-

Indirect pulp treatment, Mineral

Trioxide Aggregate and Calcium

Hydroxide

\section{Abstract}

Background: Different materials were used in the treatment of deeply decayed vital teeth. For many years, the gold standard for indirect pulp capping procedures was Calcium hydroxide. Nevertheless, the disadvantages reported with its use has led to its replacement with other materials such as mineral trioxide aggregate.

Objective: The purpose of this systematic review is to compare the effectiveness of mineral trioxide aggregate (MTA) and calcium hydroxide $(\mathrm{CH})$ in indirect pulp treatment of permanent teeth.

Methods: Detailed search on PubMed, Web of science, Cochrane Library, Google and Ebsco databases was performed. Studies meeting the criteria for inclusion were accepted, and necessary information was independently extracted by 2 authors by means of a standardized form. Evaluation was done for the success rate and dentin bridge formation.

Results: The inclusion criteria were met in three studies that were processed for data extraction and qualitative assessment.

Conclusions: Due to presence of high risk of bias in the included studies, there is no conclusive evidence on the superiority of one material over the other.

Copy Right, IJAR, 2017,. All rights reserved.

\section{Background:-}

The conventional procedure for indirect pulp treatment comprises the application of a bacteriostatic/bactericidal agent, such as calcium hydroxide, over the remaining dentin caries to encourage remineralization and pulp protection (Falster et al., 2002). However, several weaknesses were documented with the use of calcium hydroxide material as: the presence of tunnels in dentin barrier, excessive dentin formation obliterating the pulp chamber, absence of adhesion and solubility in oral fluids (Accorinte et al., 2008). New materials have evolved recently as alternatives to $\mathrm{CH}$ because of its fore mentioned disadvantages. MTA became a widespread alternative for $\mathrm{CH}$ (Camilleri 2008).

This systematic review aimed to compare the effectiveness of mineral trioxide aggregate (MTA) and calcium hydroxide $(\mathrm{CH})$ in indirect pulp treatment of permanent teeth. 


\section{Materials and Methods:-}

Identifying the review Question:-

Firstly, a PICO structure (Patient, Intervention, Comparators, Outcome) was used for the development of the research question as follows:

Patient / Population: Permanent teeth with deep caries.

Intervention: Indirect pulp treatment using Mineral trioxide aggregate

Control/ Comparator: Indirect pulp treatment using Calcium hydroxide.

Outcome measures: success rate and dentin bridge formation.

\section{Research Question:-}

In deeply decayed permanent teeth, will indirect pulp treatment using $\mathrm{CH}$ in comparison to indirect pulp treatment using MTA differ in terms of success rate and dentin bridge formation?

\section{Search Strategy:-}

In the present study, PubMed, Web of science, the Cochrane Library, Google and Ebsco were used as the electronic databases. The following key words were used: indirect pulp capping, indirect pulp cap, indirect pulp therapy, indirect pulp treatment, MTA, mineral trioxide aggregate, calcium hydroxide and $\mathrm{Ca}(\mathrm{OH}) 2$. Additional search methods included a manual review of the reference lists of relevant studies.

Figure 1. Flow diagram for the search results.

\section{Inclusion Criteria:-}

1. Randomized controlled trials (RCTs),

2. Indirect pulp treatment on permanent teeth,

3. Studies comparing mineral trioxide aggregate and calcium hydroxide,

4. The success rate and or dentin bridge formation were recorded.

\section{Data Extraction:-}

Studies that fulfilled the inclusion criteria were processed for data extraction. Two authors independently extracted the necessary information. The following information were extracted from each study: year of publication, country of origin, study design, informed consent obtained, ethical approval, funding, setting, aim of the study, participants age, numbers and gender, inclusion and exclusion criteria, details of material, methods, restoration, duration of follow up, principal and secondary outcome measures, methods of assessing outcome measures and studies results.

\section{Methodological Quality Appraisal:-}

Assessment of the quality of included studies was performed using the Cochrane Collaboration's tool for assessing risk of bias.

\section{Results:-}

Results Characteristics of Included Studies:-

From 62 potentially relevant studies, only 3 studies were eligible (Leye Benoist et al. 2012, Petrou et al $\mathbf{2 0 1 4}$ and Sultana et al. 2016). Two studies reported the success rate (Leye Benoist et al. 2012 and Petrou et al. 2014). The success rate was higher for MTA compared to $\mathrm{CH}$ in both studies as follows: (MTA 94.5\%, $\mathrm{CH} 86.9 \%, \mathrm{p}=0.72$ ) and $(89.6 \%$ with MTA, and $73 \%$ with $\mathrm{CH}, \mathrm{P}=0.63$ ). Also, two studies (Leye Benoist et al. 2012 and Sultana et al. 2016) reported the dentin bridge formation. Leye Benoist et al $\mathbf{2 0 1 2}$ showed that at 6 months, there was an increase of $0.235 \mathrm{~mm}$ with MTA and of $0.221 \mathrm{~mm}$ with $\mathrm{CH}$. No statistically significant difference was found in the dentine thickness between the two groups. While, Sultana et al. 2016 showed that at 12 months' observation period, 24 teeth $(96 \%)$ of MTA and 19 teeth $(76 \%)$ of $\mathrm{CH}$ with reparative dentin formation. 


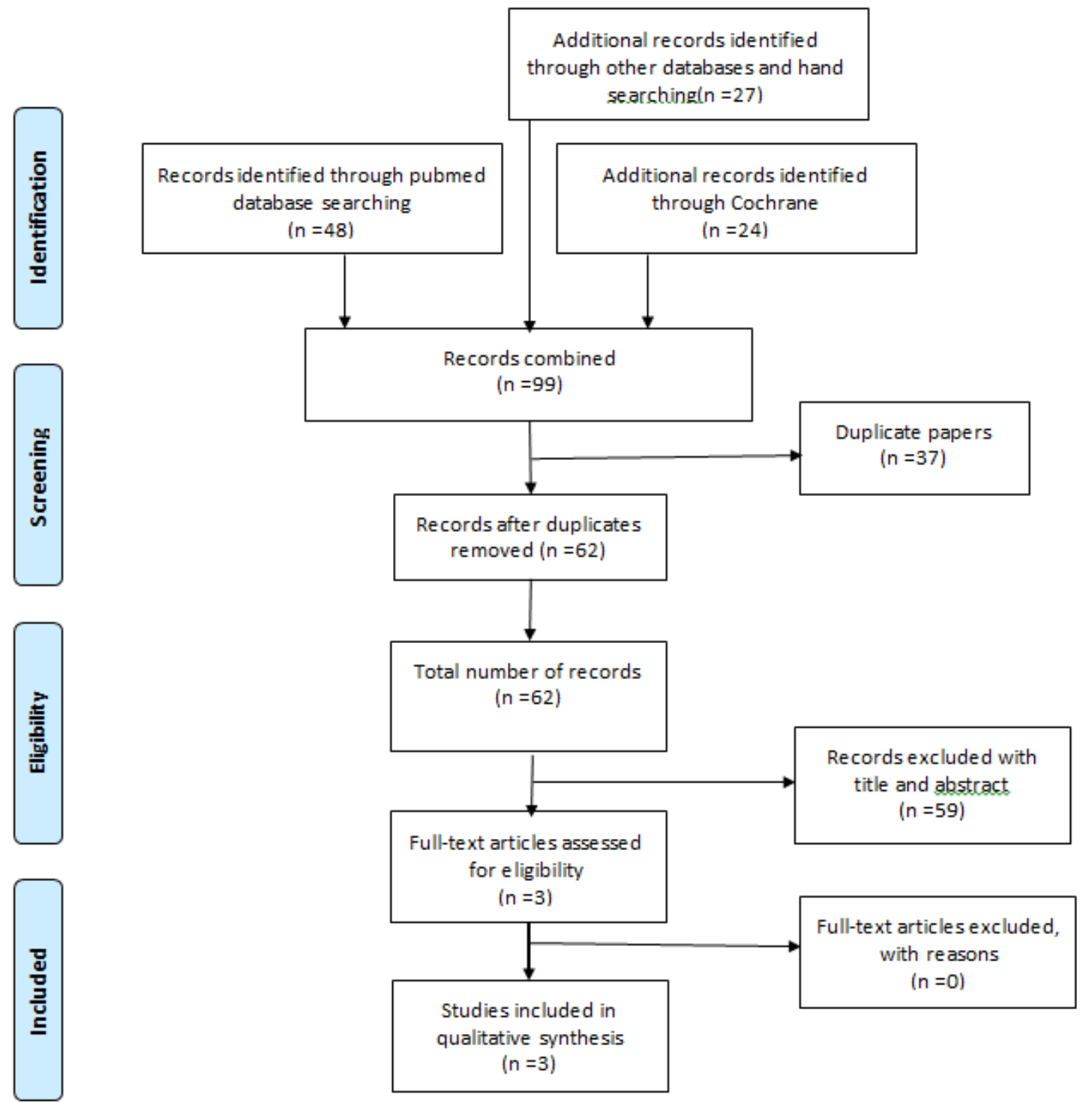

Figure 1:- Flow diagram for the search results.

\section{Results of Methodological Quality Assessment:-}

The three studies were assessed using the Cochrane Collaboration's tool for assessing risk of bias. Table 4, shows the findings for each risk of bias in each study. All studies revealed randomization, but they failed to define means for random sequence generation and did not sufficiently define allocation concealment. Blinding of the participants and personnel was mentioned in only one study that MTA and $\mathrm{CH}$ could be distinguished by the operator and so a double-blind clinical trial was not possible. Regarding the assessments of the outcomes in two studies, there was blinding of the assessor and detection bias was considered low risk. A description of withdrawals and dropouts was given in two studies. other sources of bias were not found in the three studies. 
Table 1:- The Characteristics of the Included Studies.

\begin{tabular}{|c|c|c|c|c|c|c|c|c|}
\hline Reference & & \multicolumn{7}{|c|}{ Details of Study } \\
\hline & $\begin{array}{l}\text { Count } \\
\text { ry of } \\
\text { origin }\end{array}$ & $\begin{array}{l}\text { Year of } \\
\text { publicati } \\
\text { on }\end{array}$ & $\begin{array}{l}\text { Study } \\
\text { design }\end{array}$ & $\begin{array}{l}\text { Inform } \\
\text { ed } \\
\text { consent } \\
\text { obtaine } \\
\text { d? }\end{array}$ & $\begin{array}{l}\text { Ethical } \\
\text { approval }\end{array}$ & Funding & Setting & Aim of study \\
\hline $\begin{array}{r}\text { Petrou et } \\
\text { al. } 2014\end{array}$ & $\begin{array}{l}\text { Germ } \\
\text { any }\end{array}$ & 2014 & $\begin{array}{l}\text { prospecti } \\
\text { ve in } \\
\text { vivo } \\
\text { clinical } \\
\text { trial with } \\
\text { three } \\
\text { parallel } \\
\text { treatment } \\
\text { s } \\
\text { arms }\end{array}$ & yes & $\begin{array}{l}\text { The study } \\
\text { was } \\
\text { approved } \\
\text { by the } \\
\text { ethical } \\
\text { committe } \\
\text { e } \\
\text { Universit } \\
\text { y of } \\
\text { Greifswal } \\
\text { d/German } \\
\text { y }\end{array}$ & $\begin{array}{l}\text { Not } \\
\text { mention } \\
\text { ed }\end{array}$ & $\begin{array}{l}\text { The } \\
\text { dental } \\
\text { clinic of } \\
\text { Greifswa } \\
\text { ld } \\
\text { Universit } \\
\text { y and in } \\
\text { a private } \\
\text { practice. }\end{array}$ & $\begin{array}{l}\text { To compare the } \\
\text { clinical and } \\
\text { microbiological } \\
\text { outcomes of mineral } \\
\text { trioxide aggregate } \\
\text { (MTA), medical } \\
\text { Portland cement, and } \\
\text { calcium hydroxide on } \\
\text { the dentin-pulp } \\
\text { complex of } \\
\text { permanent and } \\
\text { primary teeth treated } \\
\text { with two-step IPT. }\end{array}$ \\
\hline $\begin{array}{l}\text { Leye } \\
\text { Benoist et } \\
\text { al. } 2012\end{array}$ & $\begin{array}{l}\text { Seneg } \\
\text { al }\end{array}$ & 2012 & $\begin{array}{l}\text { single- } \\
\text { blind } \\
\text { clinical } \\
\text { trial }\end{array}$ & yes & $\begin{array}{l}\text { The study } \\
\text { had been } \\
\text { approved } \\
\text { by the } \\
\text { ethics } \\
\text { commissi } \\
\text { on the } \\
\text { of tinstitution } \\
\text {. }\end{array}$ & $\begin{array}{l}\text { The } \\
\text { study } \\
\text { was not } \\
\text { finance } \\
\text { d by } \\
\text { any } \\
\text { compan } \\
\text { y or } \\
\text { manufa } \\
\text { cturer } \\
\text { and has } \\
\text { no } \\
\text { commer } \\
\text { cial } \\
\text { aim. }\end{array}$ & $\begin{array}{l}\text { The } \\
\text { faculty } \\
\text { clinic of } \\
\text { the } \\
\text { Departm } \\
\text { ent } \\
\text { of } \\
\text { Dentistry } \\
\text { Universit } \\
\text { y Cheikh } \\
\text { Anta } \\
\text { Diop, } \\
\text { Dakar, } \\
\text { Senegal. }\end{array}$ & $\begin{array}{l}\text { To assess the } \\
\text { effectiveness } \\
\text { mineral of } \\
\text { aggregate } \\
\text { used as an indirect } \\
\text { pulp-capping material } \\
\text { in human } \\
\text { molar and premolar } \\
\text { teeth. }\end{array}$ \\
\hline $\begin{array}{l}\text { Sultana et } \\
\text { al. } 2016\end{array}$ & $\begin{array}{l}\text { Bangl } \\
\text { adesh }\end{array}$ & 2016 & $\begin{array}{l}\text { prospecti } \\
\text { ve } \\
\text { comparat } \\
\text { ive study. }\end{array}$ & yes & $\begin{array}{l}\text { The } \\
\text { proposed } \\
\text { study } \\
\text { protocol } \\
\text { was } \\
\text { approved } \\
\text { by the } \\
\text { Ethical } \\
\text { Review } \\
\text { Committee } \\
\text {, BSMMU }\end{array}$ & $\begin{array}{l}\text { Not } \\
\text { mention } \\
\text { ed }\end{array}$ & $\begin{array}{l}\text { The } \\
\text { Departme } \\
\text { nt of } \\
\text { Conservat } \\
\text { ive } \\
\text { Dentistry } \\
\text { and } \\
\text { Endodonti } \\
\text { cs, } \\
\text { Faculty of } \\
\text { Dentistry, } \\
\text { BSMMU }\end{array}$ & $\begin{array}{l}\text { To assess the clinical } \\
\text { and radiological } \\
\text { outcomes of MTA } \\
\text { and calcium } \\
\text { hydroxide as indirect } \\
\text { pulp capping agents } \\
\text { in deep carious } \\
\text { lesions of permanent } \\
\text { teeth }\end{array}$ \\
\hline
\end{tabular}

Table 2:- Data Extraction of the Included Studies (participants and intervention).

\begin{tabular}{|c|c|c|c|c|c|c|c|c|c|}
\hline & \multicolumn{4}{|c|}{ Participants } & \multicolumn{5}{|c|}{ Interventions } \\
\hline & $\begin{array}{l}\text { Numbe } \\
\mathrm{r}\end{array}$ & Age: & $\begin{array}{l}\text { Ge } \\
\text { nd } \\
\text { er }\end{array}$ & $\begin{array}{l}\text { Inclusion and } \\
\text { exclusion criteria }\end{array}$ & $\begin{array}{l}\text { Group } \\
\text { ing }\end{array}$ & $\begin{array}{l}\text { Details of } \\
\text { material }\end{array}$ & $\begin{array}{l}\text { Met } \\
\text { hods }\end{array}$ & Final rest & $\begin{array}{l}\text { Durati } \\
\text { on of } \\
\text { Follo } \\
\text { w up }\end{array}$ \\
\hline $\begin{array}{l}\text { Petrou } \\
\text { et al. }\end{array}$ & $\begin{array}{l}\text { Eighty- } \\
\text { six }\end{array}$ & $\begin{array}{l}17.2 \\
\text { year }\end{array}$ & $\begin{array}{l}- \\
51\end{array}$ & $\begin{array}{l}\text { (a) deep caries lesion } \\
\text { with absence of }\end{array}$ & $\begin{array}{l}\text { Three } \\
\text { groups }\end{array}$ & $\begin{array}{l}\text { (a) Aqueous } \\
\text { suspension of }\end{array}$ & $\begin{array}{l}\text { Parti } \\
\text { al }\end{array}$ & $\begin{array}{l}\text { Glass } \\
\text { ionomer }\end{array}$ & $6 \mathrm{~m}$ \\
\hline
\end{tabular}




\begin{tabular}{|c|c|c|c|c|c|c|c|c|c|}
\hline 2014 & teeth & $\begin{array}{l}\text { s } \\
\pm 13 \text {. } \\
8\end{array}$ & $\begin{array}{l}\% \\
\text { M } \\
\text { ale } \\
; \\
- \\
49 \\
\% \\
\mathrm{Fe} \\
\mathrm{m} \\
\text { ale }\end{array}$ & 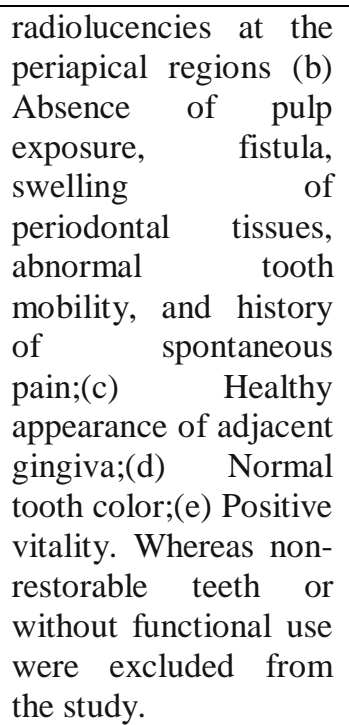 & $\begin{array}{l}: \\
\text { (a) } \\
\text { calciu } \\
\mathrm{m} \\
\text { hydro } \\
\text { xide } \\
\text { (b) } \\
\text { medic } \\
\text { al } \\
\text { Portla } \\
\text { nd } \\
\text { cemen } \\
\mathrm{t} \\
\text { (c) } \\
\text { pure } \\
\text { White } \\
\text { MTA }\end{array}$ & $\begin{array}{l}\text { calcium } \\
\text { hydroxide } \\
\text { (Greifswald } \\
\text { University } \\
\text { Pharmacy, } \\
\text { Germany); } \\
\text { (b) medical } \\
\text { Portland cement } \\
\text { (Holcim } \\
\text { 103, White } \\
\text { Portland } \\
\text { Cement CEM) } \\
\text { (c) pure White } \\
\text { MTA } \\
\text { (Ledermix }{ }^{\circledR} \\
\text { MTA, Riemser) }\end{array}$ & $\begin{array}{l}\text { carie } \\
\text { s } \\
\text { remo } \\
\text { val } \\
\text { on } 2 \\
\text { visit } \\
\mathrm{s}, 6 \\
\text { mont } \\
\text { hs } \\
\text { inter } \\
\text { val }\end{array}$ & $\begin{array}{l}\text { resin- } \\
\text { enforced } \\
\text { zinc oxide } \\
\text { eugenol } \\
\text { followed } \\
\text { by } \\
\text { Compome } \\
\text { r and } \\
\text { amalgam }\end{array}$ & \\
\hline $\begin{array}{l}\text { Leye } \\
\text { Benois } \\
\text { t et al. } \\
2012\end{array}$ & $\begin{array}{l}60 \\
\text { paired } \\
\text { perman } \\
\text { ent } \\
\text { teeth } \\
(30 \\
\text { in each } \\
\text { group) }\end{array}$ & $\begin{array}{l}16- \\
34 \\
\text { year } \\
\text { s }\end{array}$ & $\begin{array}{l}- \\
34 \\
\mathrm{M} \\
\text { ale } \\
- \\
26 \\
\mathrm{Fe} \\
\mathrm{m} \\
\text { ale }\end{array}$ & $\begin{array}{l}\text { Active deep carious } \\
\text { lesion on either the } \\
\text { occlusal or proximal } \\
\text { surface with reversible } \\
\text { pulp inflammation. } \\
\text { Teeth with } \\
\text { periodontal lesions, } \\
\text { internal or external } \\
\text { root resorptions, and } \\
\text { patients with systemic } \\
\text { medical conditions, } \\
\text { were excluded from } \\
\text { the study. }\end{array}$ & $\begin{array}{l}\text { Two } \\
\text { groups } \\
: \\
\text { (a) } \\
\text { calciu } \\
\text { m } \\
\text { hydro } \\
\text { xide } \\
\text { (b) } \\
\text { MTA }\end{array}$ & $\begin{array}{l}\text { MTA (ProRoot; } \\
\text { Dentsply / Tulsa } \\
\text { Dental, Tulsa, } \\
\text { OK, } \\
\text { USA) and } \\
\text { calcium } \\
\text { hydroxide } \\
\text { material } \\
\text { (Dycal_Ivory, } \\
\text { Dentsply Caulk, } \\
\text { Dentsply, L.D. } \\
\text { Caulk, Milford, } \\
\text { DE, USA) }\end{array}$ & $\begin{array}{l}\text { One } \\
\text { visit }\end{array}$ & $\begin{array}{l}\text { Glass } \\
\text { ionomer } \\
\text { cement } \\
\text { placed } \\
\text { during the } \\
6 \text {-month } \\
\text { evaluation } \\
\text { period . } \\
\text { The final } \\
\text { restoration } \\
\text { was either } \\
\text { amalgam } \\
\text { or } \\
\text { composite }\end{array}$ & $6 \mathrm{~m}$ \\
\hline $\begin{array}{l}\text { Sultan } \\
\text { a et al. } \\
2016\end{array}$ & $\begin{array}{l}\text { Fifty } \\
\text { perman } \\
\text { ent } \\
\text { teeth } \\
\text { from } \\
43 \\
\text { patients }\end{array}$ & $\begin{array}{l}16- \\
30 \\
\text { year } \\
\text { s }\end{array}$ & & $\begin{array}{l}\text { Permanent teeth } \\
\text { having a deep carious } \\
\text { lesion closer to but not } \\
\text { involving the pulp, } \\
\text { having reversible pulp } \\
\text { status based on the } \\
\text { clinical sign, } \\
\text { symptom, and } \\
\text { radiograph and could } \\
\text { be restorable. }\end{array}$ & $\begin{array}{l}\text { Two } \\
\text { groups } \\
: \\
\text { (a) } \\
\text { calciu } \\
\text { m } \\
\text { hydro } \\
\text { xide } \\
\text { (b) } \\
\text { MTA }\end{array}$ & $\begin{array}{l}\text { Calcium } \\
\text { hydroxide } \\
\text { powder (Deepti } \\
\text { Dental Product, } \\
\text { India) mixed } \\
\text { with normal } \\
\text { saline } \\
\text { MTA (Proroot, } \\
\text { Dentsply, Tulsa } \\
\text { Dental, USA) } \\
\text { powder } \\
\text { mixed with } \\
\text { sterile water in a } \\
3: 1 \text { ratio. }\end{array}$ & $\begin{array}{l}\text { One } \\
\text { visit }\end{array}$ & $\begin{array}{l}\text { The base } \\
\text { of the } \\
\text { cavity was } \\
\text { filled with } \\
\text { FujiIX } \\
\text { glass } \\
\text { ionomer } \\
\text { cement } \\
\text { and } \\
\text { restored } \\
\text { by } \\
\text { composite } \\
\text { restoration } \\
\text { (Giomer) }\end{array}$ & $12 \mathrm{~m}$ \\
\hline
\end{tabular}


Table 3:- Data Extraction of the Included Studies (outcomes and results)

\begin{tabular}{|c|c|c|c|}
\hline \multirow[t]{2}{*}{ Reference } & \multicolumn{2}{|r|}{ outcome } & \multirow[t]{2}{*}{ Results } \\
\hline & $\begin{array}{l}\text { Principal and } \\
\text { secondary } \\
\text { outcome } \\
\text { measures }\end{array}$ & $\begin{array}{l}\text { Methods of assessing outcome } \\
\text { measures }\end{array}$ & \\
\hline $\begin{array}{l}\text { Petrou et } \\
\text { al. } 2014\end{array}$ & $\begin{array}{l}\text { The success rate } \\
\text {-Clinical (color, } \\
\text { humidity, and } \\
\text { consistency of } \\
\text { dentin) } \\
\text {-Microbiological } \\
\text { (Lactobacilli/Mu } \\
\text { tans Strep. } \\
\text { counts) }\end{array}$ & $\begin{array}{l}\text {-The color of the dentin either: } \\
\text { light yellow, yellow, light brown, } \\
\text { dark brown, or black. } \\
\text {-The consistency of the dentin } \\
\text { either: very soft, soft medium } \\
\text { hard or hard } \\
\text { - The existence of } \\
\text { humidity(wet/dry) }\end{array}$ & $\begin{array}{l}\text { The success rate (MTA 94.5 \%, Portland } \\
\text { cement } 90.5 \%, \mathrm{CH} 86.9 \%, \chi 2 \text {-test } \mathrm{p}=0.72) \text {. }\end{array}$ \\
\hline $\begin{array}{l}\text { Leye } \\
\text { Benoist et } \\
\text { al. } 2012\end{array}$ & $\begin{array}{l}\text { The success rate } \\
\text { and the thickness } \\
\text { of the newly } \\
\text { formed dentine }\end{array}$ & $\begin{array}{l}\text {-Maintenance of pulp vitality } \\
\text { with a normal response to thermal } \\
\text { and electrical tests without signs } \\
\text { of spontaneous pain. } \\
\text {-Dentine bridge formation and no } \\
\text { furcation radiolucency, } \\
\text { periodontal ligament space } \\
\text { widening, internal or external root } \\
\text { resorptions. }\end{array}$ & $\begin{array}{l}\text { At } 3 \text { months, the clinical success rates of MTA } \\
\text { and calcium hydroxide were } 93 \% \text { and } 73 \% \text {, } \\
\text { respectively }(\mathrm{P}=0.02) \text {. At } 6 \text { months, the } \\
\text { success rate was } 89.6 \% \text { with MTA, and } \\
\text { remained steady at } 73 \% \text { with calcium } \\
\text { hydroxide }(\mathrm{P}=0.63) \text {. } \\
\text { The mean initial residual dentine thickness } \\
\text { was } 0.23 \mathrm{~mm} \text {, and increased by } 0.121 \mathrm{~mm} \\
\text { with MTA and by0.136 mm with calcium } \\
\text { hydroxide at } 3 \text { months. At } 6 \text { months, there was } \\
\text { an increase of } 0.235 \text { mm with MTA and of } \\
0.221 \text { mm with calcium hydroxide }\end{array}$ \\
\hline $\begin{array}{l}\text { Sultana et } \\
\text { al. } 2016\end{array}$ & $\begin{array}{l}\text { Postoperative } \\
\text { pain, the vitality } \\
\text { of the pulp and } \\
\text { formation of } \\
\text { reparative dentin }\end{array}$ & $\begin{array}{l}\text { Pain assessment was performed } \\
\text { according to VAS } \\
\text { (Visual Analogue Scale) system. } \\
\text { Pulp vitality was assessed by } \\
\text { vitality test. } \\
\text { Reparative dentin formation was } \\
\text { assessed by means of intraoral } \\
\text { periapical radiograph (IOAP). } \\
\text { Reparative dentin formation was } \\
\text { observed (present/absent) from } \\
\text { the radiograph. }\end{array}$ & $\begin{array}{l}\text { In all observation periods, MTA showed more } \\
\text { capable of reducing pain and maintain pulp } \\
\text { vitality which was statistically significant than } \\
\text { that of calcium hydroxide. } \\
\text { At } 12 \text { months observation period, } 24 \text { teeth } \\
(96 \%) \text { of MTA and } \\
19 \text { teeth } 76 \% \text { ) of calcium hydroxide showed } \\
\text { reparative dentin } \\
\text { (formation. }\end{array}$ \\
\hline
\end{tabular}

Table 4:- Assessment of the quality of included studies

\begin{tabular}{|c|c|c|c|c|c|c|}
\hline & $\begin{array}{c}\text { Random } \\
\text { sequence } \\
\text { generation* }\end{array}$ & $\begin{array}{l}\text { Allocation } \\
\text { concealment }\end{array}$ & $\begin{array}{l}\text { Blinding of } \\
\text { participants } \\
\text { and personnel }\end{array}$ & $\begin{array}{l}\text { Blinding of } \\
\text { outcome } \\
\text { assessment. }\end{array}$ & $\begin{array}{l}\text { Incomplete } \\
\text { outcome data }\end{array}$ & $\begin{array}{l}\text { Selective } \\
\text { reporting }\end{array}$ \\
\hline $\begin{array}{c}\text { Leye } \\
\text { Benoist et } \\
\text { al. } 2012\end{array}$ & High risk & High risk & $\begin{array}{l}\text { Participants: } \\
\text { unclear } \\
\text { Operator: } \\
\text { Low risk }\end{array}$ & $\begin{array}{l}\text { Clinical assessor: } \\
\text { unclear } \\
\text { Rad. Assessor: } \\
\text { Low risk }\end{array}$ & Low risk & Unclear \\
\hline $\begin{array}{c}\text { Petrou et al. } \\
2014\end{array}$ & Unclear & Unclear & Unclear & Unclear & High risk & High risk \\
\hline $\begin{array}{c}\text { Sultana et } \\
\text { al. } 2016 \\
\end{array}$ & Unclear & Unclear & Unclear & Low risk & Unclear & Unclear \\
\hline
\end{tabular}

\section{Interpretation:-}

The available studies showed a higher success rate for MTA compared to $\mathrm{CH}$. Also, more dentin bridge formation was shown with MTA. Regarding the quality of the investigated studies (Table 4), a high risk of bias was found. 


\section{Conclusions:-}

Due to presence of high risk of bias in the included studies, there is no conclusive evidence on the superiority of one material over the other.

Further, high quality and long span clinical trials for indirect pulp treatment materials are still required to assess the most effective material owing to the high risk of bias and the short-term follow-up in the available studies.

\section{References:-}

1. Accorinte, M.D.L.R. et al., 2008. Evaluation of mineral trioxide aggregate and calcium hydroxide cement as pulp-capping agents in human teeth. Journal of endodontics, 34(1), pp.1-6.

2. Camilleri, J., 2008. Characterization of hydration products of mineral trioxide aggregate. International Endodontic Journal, 41(5), pp.408-417.

3. Falster, C. a et al., 2002. Indirect pulp treatment: in vivo outcomes of an adhesive resin system vs calcium hydroxide for protection of the dentin-pulp complex. Pediatric dentistry, 24(3), pp.241-8.

4. Leye Benoist, F. et al., 2012. Evaluation of mineral trioxide aggregate (MTA) versus calcium hydroxide cement (Dycal(®) ) in the formation of a dentine bridge: a randomised controlled trial. International dental journal, 62(1), pp.33-9.

5. Petrou, M.A. et al., 2014. A randomized clinical trial on the use of medical Portland cement, MTA and calcium hydroxide in indirect pulp treatment. Clinical oral investigations.

6. Sultana, R., Hossain, M. \& Alam, S., 2016. Evaluation of clinical and radiological outcomes of mineral trioxide aggregate and calcium hydroxide as indirect pulp capping agents in the treatment of deep carious lesion of permanent teeth. , pp.1-9. 